Western University

Scholarship@Western

Geography Publications

Geography Department

6-1988

Effective Discharge for Suspended Sediment Transport in Streams of the Saskatchewan River Basin

Peter Ashmore

University of Western Ontario

T J. Day

Sediment Survey Section, Water Survey of Canada

Follow this and additional works at: https://ir.lib.uwo.ca/geographypub

Part of the Geography Commons

Citation of this paper:

Ashmore, Peter and Day, T J., "Effective Discharge for Suspended Sediment Transport in Streams of the Saskatchewan River Basin" (1988). Geography Publications. 294.

https://ir.lib.uwo.ca/geographypub/294 


\title{
Effective Discharge for Suspended Sediment Transport in Streams of the Saskatchewan River Basin
}

\author{
P. E. ASHMORE \\ Department of Geography, University of Saskatchewan, Saskatoon, Saskatchewan, Canada
}

T. J. DAY

Sediment Survey Section, Water Resources Branch, Inland Waters/Lands Directorate, Environment Canada, Ottawa, Ontario

\begin{abstract}
Effective discharge for suspended sediment load was determined for 21 sites in the Saskatchewan River basin at which sediment records range from 5 to 29 years in length. The drainage areas for these streams ranges from 10 to over $300,000 \mathrm{~km}^{2}$. The sediment discharge histograms have a variety of forms ranging from the classic unimodal form in which the peak occurs at discharges with a duration of $1-3 \%$ to those in which the effective discharge is the extreme event of record and cases in which a single effective discharge is difficult to define. The percentage duration of the effective discharge ranges from less than $0.1 \%$ to over $15 \%$, a greater range than previously has been reported. There is an obvious tendency for the percentage duration of the effective discharge to increase with drainage area and hence downstream
through the drainage system.
\end{abstract}

\section{INTRODUCTION}

One of the tenets of fluvial geomorphology is that while sediment transport occurs over a wide range of discharges, the flows which, over the long term, accomplish the most work are those of moderate magnitude, close to bank-full, typically recurring once or twice/year [Wolman and Miller, 1960]. The notion of "work done" (sediment transported) by events of a given magnitude and frequency is distinct from, but related to, the effectiveness of these events in controlling channel form. Wolman and Miller [1960] suggested that in humid temperate environments the effective discharge for sediment transport would be very similar in magnitude to the dominant discharge controlling channel morphology.

Wolman and Miller [1960] proposed that the amount of sediment transported by flows of a given magnitude depends on the form of the relationship between discharge and sediment load and on the frequency distribution of the discharge events. The product of transport rate and frequency gives the cumulative sediment load transported by a given discharge. Given a lognormal discharge frequency distribution and a power relationship between discharge and sediment load, the curve relating discharge to cumulative sediment load has a single maximum at some fairly high magnitude, but not extreme, discharge referred to as the effective discharge [Pickup and Warner, 1976; Andrews, 1980].

The duration of the effective discharge varies with the form of the frequency distribution of discharge and therefore with factors such as drainage area, drainage basin topography, and geology and the temporal pattern of precipitation inputs, and is also influenced by the nature of the sediment load. Thus Wolman and Miller [1960] demonstrated that the significance of high magnitude events was greater in smaller drainage basins and in ephemeral streams, while Andrews [1980] showed that the effective discharge for total sediment load was less frequent in smaller drainage basins which have more skewed daily discharge duration curves. The influence of sedi-

Copyright 1988 by the American Geophysical Union.

Paper number 7 W5038.

0043-1397/88/007W-5038\$05.00 ment type is likely to be manifested in the effective discharge for bed load being a higher magnitude event than that for suspended load, because the threshold of motion is much higher for coarser bed load particles than for finer suspended sediment [Baker, 1977; Richards, 1982, p. 145].

There have been few attempts to confirm the validity of the effective discharge concept for fluvial sediment transport and to establish the magnitude of variation in its duration. Benson and Thomas [1966] showed that histograms of total load transported by increments of the discharge range could be used to identify the effective discharge. Their data indicate that the average percentage duration of the effective discharge for streams with drainage areas ranging from 584 to 357,000 $\mathrm{km}^{2}$ is approximately $12 \%$. These are more frequent discharges than those suggested by Wolman and Miller [1960]. The fact that similar quantities of sediment were transported by a wide range of discharges also lead Benson and Thomas to question the validity and applicability of the effective discharge concept. In particular, they pointed out that the effective discharge for suspended sediment transport was a smaller magnitude event than the "dominant" discharge to which the channel form responds. Contrary to Benson and Thomas's [1966] results, more recent analyses by Andrews [1980] for the total load, Pickup and Warner [1976] for bed load and Webb and Walling [1982] for suspended sediment have shown that the effective discharge is a relatively frequent event exceeded between 1 and 10 days/year $(0.35-3 \%$ of the time). Nolan et al. [1987] report effective discharges with frequencies toward the lower end of this range (2-4 days/year).

The relationship between the effective discharge for sediment transport and the dominant discharge for channel formation appears to vary. Andrews' [1980] samples of streams in the Yampa River basin have an effective discharge for total sediment load of almost identical magnitude to the bank-full discharge. However, Pickup and Warner [1976] found that the effective discharge for bed load transport had a lower return period than the bank-full discharge, and Benson and Thomas [1966] clearly demonstrate that the effective discharge for suspended sediment load is well below bank-full. Recent data from northern California [Nolan et al., 1987] also show that 
the effective discharge is considerably below bank-full. It is now apparent that the dominant discharge for channel morphology is also subject to considerable variation controlled in part by environmental conditions, the recovery time for large floods [Wolman and Gerson, 1978], and the threshold for sediment transport [Baker, 1977]. Thus it appears likely that not only is the effective discharge for suspended sediment transport more variable in relative magnitude than Wolman and Miller [1960] suggested but also the effective discharge for sediment transport may not always be similar in magnitude to the dominant discharge for channel morphology.

The purpose of this paper is to add to the existing information on the magnitude and duration of the effective discharge for suspended sediment transport and in particular to present evidence from a large drainage basin in western Canada that the duration of the effective discharge may vary more widely than has previously been reported, as a result of differences in basin area, streamflow regime, and perhaps the nature of the sediment load. The drainage areas of many of these streams are comparable with those used by Benson and Thomas [1966] and considerably greater than those used in most other previous investigations.

\section{SASKatchewan River Basin}

The Saskatchewan River upstream of The Pas, Manitoba drains a total area of $347,000 \mathrm{~km}^{2}$ east of the continental divide including much of the Alberta and Saskatchewan Plains (Figure 1). The drainage system consists of two main branches, the North and South Saskatchewan River which join in central Saskatchewan about $300 \mathrm{~km}$ upstream of The Pas. The river empties into Cedar Lake and from there into Lake Winnipeg.

There are few large natural lakes in the system apart from the Cumberland Lake and Delta region in east-central Saskatchewan. However, there are several large reservoirs, notably Abraham Lake on the North Saskatchewan River, Lake Diefenbaker on the South Saskatchewan River, and Tobin Lake on the Saskatchewan River. In addition, there a number of smaller power dams in the headwaters of the Bow River and several onstream and offstream reservoirs associated with irrigation in the Bow, Oldman, and South Saskatchewan River basins. Flow regulation at these sites may influence the effective discharge at some downstream stations on these rivers; details of this are discussed below.

By far the largest portion of the area of the basin lies within the Alberta and Saskatchewan Plains where relief is low except where the major rivers have incised deep valleys. The topography changes dramatically on the western margin of the basin where the Plains give way to the Rocky Mountains and Foothills. It is this region of the basin, where annual precipitation is highest, which supplies much of the runoff to the large Plains streams. Roughly $70 \%$ of the streamflow in the larger streams is supplied from the portion of the basin upstream of Edmonton, Red Deer, Calgary, and Lethbridge.

Close to the Mountains the annual runoff regime shows a single peak in May, June, or July (depending on the proximity to the Mountains) derived from snowmelt (and in some cases glacier melt as well) and spring and early summer rainfall. This runoff is routed downstream but further east it is often preceeded by a smaller peak derived from Plains snowmelt and spring rain. In the case of rivers with no Mountain source this earlier snowmelt peak is usually the major runoff event of the year, although occasionally a large summer rain storm may dominate.

\section{Data}

The Water Survey of Canada (WSC) began a program of sediment data collection in the Saskatchewan River basin in 1962. As of 1983 (the last year used in this analysis), there were 27 stations with more than 4 years of data and 18 with records 10 years or more in length, up to a maximum of 29 years. Of these, 21 were chosen for effective discharge analysis. These stations are listed in Table 1, and their location is shown in Figure 1.

Data are collected according to standard Water Survey of Canada practice. A single depth-integrated suspended sediment sample is collected at a cross section which normally coincides with the discharge rated section. Usually, data are collected only during open water season (March or April to October) but in some cases (particularly during the 1960 s and early 1970s) sampling has been carried out year-round. The suspended sediment load carried during winter averages less than $5 \%$ of the annual load on these rivers [Ashmore, 1986]. Samples are collected every few days on average but more frequently during high discharges.

The concentration in the single vertical is adjusted to give a cross section average using an adjustment factor that is calculated from occasional sampling at several verticals in the cross section. The measured suspended sediment concentration is plotted alongside the continuous stage record and a continuous record of concentration is interpolated between the samples. Daily mean concentration is calculated from this curve and multiplied by the daily mean discharge to give the daily suspended sediment load. This method differs from the duration curve-sediment rating curve technique on which previous analyses of effective discharge for suspended sediment transport have been based. Consequently, the inherent bias in the rating curve method which has been revealed recently [Ferguson, 1986], and which, unless corrected, often leads to underestimation of the concentration for high discharges is not present in these data. This may have a bearing on the results reported here compared with the previously published analyses discussed above.

\section{ANALYSIS}

For each station the total suspended sediment load transported by increments of the discharge range was calculated and plotted as a histogram. The modal value, the discharge increment with the largest cumulative load, is taken to be the effective discharge. The duration of the upper and lower bounds of this discharge increment were read from the flow duration record.

\section{RESULTS}

\section{Sediment Discharge Histograms}

The form of the sediment discharge histograms varies considerably among the stations analyzed, and Figure 2 contains illustrative examples. Contrary to the expectation of unimodal histograms with clear effective discharges, a variety of forms emerged. These can best be described by grouping them into particular types.

The first of these are stations that fit the established model. Effective discharge at these stations is relatively frequent and the histogram has a well-defined single mode. This type is 


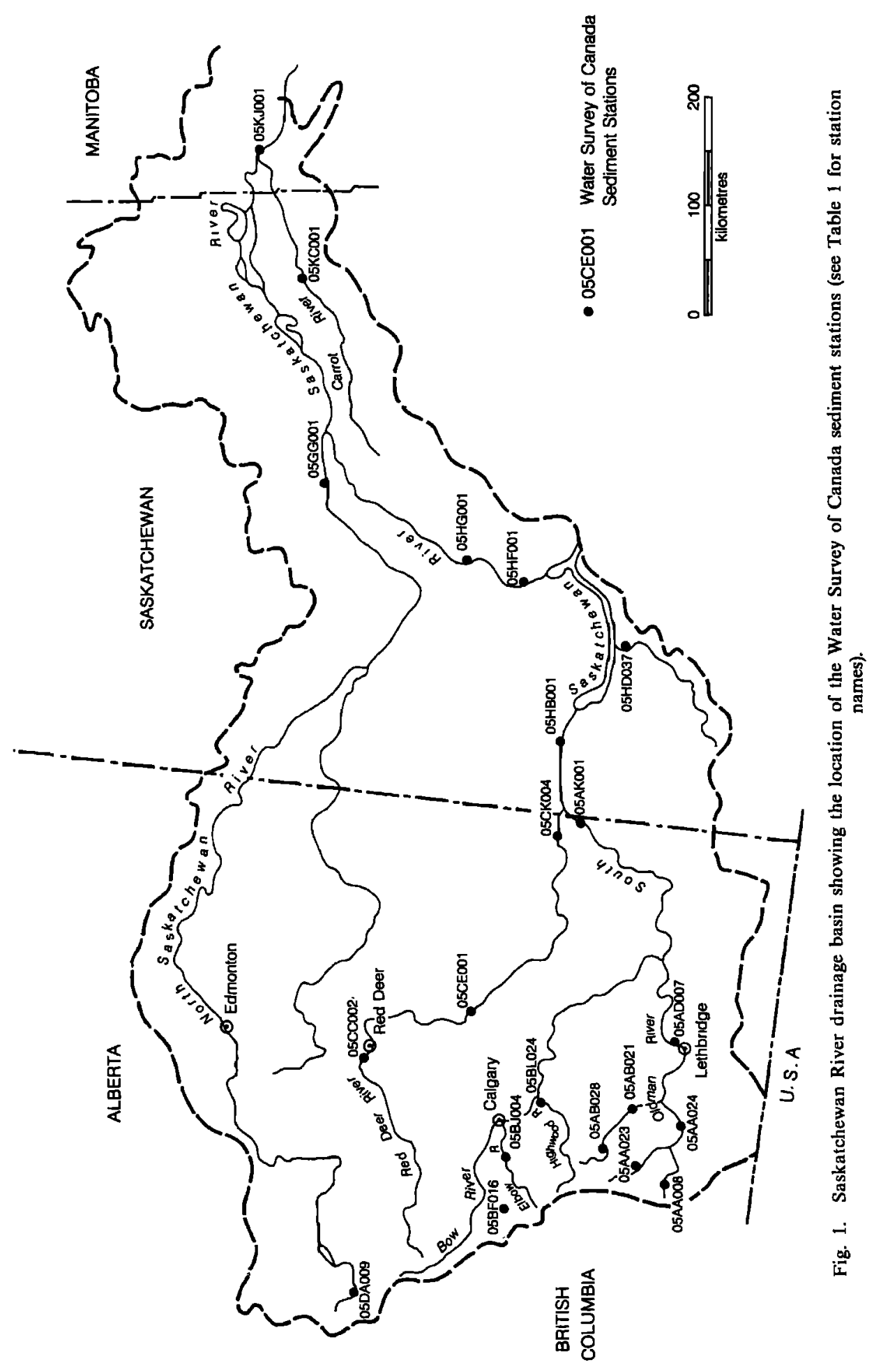


TABLE 1. Drainage Area, Mean Annual Discharge, and Effective Discharge for Stations in the Saskatchewan River Basin

\begin{tabular}{|c|c|c|c|c|c|c|}
\hline \multirow[b]{2}{*}{ WSC Station } & \multirow{2}{*}{$\begin{array}{l}\text { Station } \\
\text { Number }\end{array}$} & \multirow{2}{*}{$\begin{array}{c}\text { Drainage } \\
\text { Area, } \\
\text { km² }^{2}\end{array}$} & \multicolumn{2}{|c|}{$\begin{array}{l}\text { Length of Sediment } \\
\text { Record, years }\end{array}$} & \multicolumn{2}{|c|}{$\begin{array}{c}\text { \% Duration of Effective } \\
\text { Discharge }\end{array}$} \\
\hline & & & Seasonal & Annual & Seasonal & Annual \\
\hline Crowsnest River at Frank & 05AA008 & 402 & 5 & 1 & $1.93-3.52$ & \\
\hline Oldman River near Waldron's Corner & $05 \mathrm{AA} 023$ & 1,440 & 8 & 2 & $0.11-0.45$ & \\
\hline Oldman River near Brocket & $05 \mathrm{AA024}$ & 4,400 & 18 & 12 & $0.64-1.52$ & $0-0.02$ \\
\hline Willow Creek near Claresholm & 05AB021 & 1,100 & 11 & 10 & $0.04-0.17$ & $0.03-0.11$ \\
\hline Willow Creek above Chain Lakes & $05 \mathrm{AB} 028$ & 162 & 13 & 11 & $0-0.12$ & 0.0 .08 \\
\hline Oldman River near Lethbridge & 05AD007 & 17,000 & 12 & 6 & $1.87-4.44$ & \\
\hline South Saskatchewan River at Highway 4I & 05AK001 & 66,000 & 18 & 12 & $6.22-12.54$ & $4.29-8.24$ \\
\hline Marmot Creek main stem near Seebe & 05BF016 & 9.4 & 21 & 15 & $0.05-0.21$ & $0.05-0.21$ \\
\hline Elbow River at Bragg Creek & 05BJ004 & 792 & 7 & & $0.75-1.60$ & \\
\hline Highwood River near the mouth & 05BL024 & 3,990 & 11 & 7 & $3.26-5.68$ & \\
\hline Red Deer River at Red Deer & $05 \mathrm{CC} 002$ & 11,600 & 13 & 3 & $7.56-14.01$ & \\
\hline Red Deer River at Drumheller & 05CE001 & 24,800 & 9 & 2 & $8.73-15.62$ & \\
\hline Red Deer River near Bindless & 05CK004 & 44,700 & 18 & 12 & $15.24-47.54$ & $9.11-29.54$ \\
\hline South Saskatchewan River near Lemsford & $05 \mathrm{HB} 001$ & 119,000 & 10 & 9 & $2.96-4.98$ & \\
\hline Swift Current Creek near the mouth & 05HD037 & 3,910 & 9 & & $0.64-0.99$ & \\
\hline South Saskatchewan River near Outlook & 05HF00I & 136,000 & 12 & & $8.17-13.55$ & \\
\hline South Saskatchewan River at Saskatoon & $05 \mathrm{HG} 001$ & 141,000 & 6 & 6 & $6.80-22.45$ & $5.43-22.45$ \\
\hline North Saskatchewan River at Whirlpool Point & 05DA009 & 1,920 & 10 & 6 & $11.82-16.97$ & \\
\hline North Saskatchewan River at Prince Albert & $05 \mathrm{GG} 001$ & 131,000 & 22 & 15 & $8.76-20.61$ & $6.01-13.38$ \\
\hline Carrot River near Smoky Burn & $05 \mathrm{KCOOI}$ & 9,250 & 7 & & $2.04-2.96$ & \\
\hline Saskatchewan River at The Pas & $05 \mathrm{KJ} 001$ & 347,000 & 29 & 21 & $20.73-32.20$ & $13.95-21.71$ \\
\hline
\end{tabular}

exemplified in Figure 2 by the North Saskatchewan River at Prince Albert (05GG001) and includes most of the other stations on the large Prairie rivers with Mountain sources (Red Deer River at Drumheller (05CE001), Red Deer River at Bindloss (05CK004), South Saskatchewan River at Highway 41 (05AK001), South Saskatchewan River near Lemsford (05HB001), and South Saskatchewan River near Outlook (05HF001)).

The second group of stations are those in which an effective discharge can be recognized but the histogram has a very erratic form and discharges of widely differing durations transport similar sediment loads. In some cases the effective discharge is a relatively extreme event. Swift Current Creek is an example of this type illustrated in Figure 2. Other examples are the Crowsnest River at Frank (05AA008) and the Carrot River near Smoky Burn (05KC001). These are all relatively small drainage basins whose average annual flow regimes show a single, sharp snowmelt peak.

A third group of stations are those at which the effective discharge is within the normal duration range but the extreme events during the period of record transport sediment loads almost comparable to the effective discharge. The consequence is a histogram with at least one significant secondary peak at the extreme upper end of the discharge range. The curve for the Red Deer River at Red Deer (05CC002) shown in Figure 2 is an example of this type. Other examples include the Oldman River at Lethbridge (05AD007), the Elbow River at Bragg Creek (05BJ004), and the Highwood River near the mouth (05BL024).

The stations in the fourth group have a form similar to that of the third but differ by being dominated by the events at the upper end of the discharge range. Thus in some cases, the largest daily flow on record is the effective discharge. Cases such as these have not previously been reported. The example in Figure 2 is Willow Creek near Claresholm (05AB021). The Oldman River at Waldron's Corner (0SAA023), the Oldman River near Brocket (05AA024), Willow Creek above Chain
Lakes (05AB028), and Marmot Creek Mainstem near Seebe (05BF016) also exemplify this type. These are all fairly small Foothills streams upstream of the stations in the third group.

A fifth type of histogram can be identified in which a single mode occurs at a discharge with a duration similar to those in the first group but in which the histogram has a broad, almost flat, peak covering a wide discharge range. Both the North Saskatchewan River at Whirlpool Point (05DA009) and the Saskatchewan River at The Pas (05KJ001) have this form. In the case of the former the regime is dominated by summer snow and glacier melt from the Rocky Mountains, while the latter has a regime strongly influenced by upstream reservoir and lake storage.

\section{Duration of Effective Discharge}

Despite the erratic nature of some of the sediment discharge histograms it is possible to identify a single discharge increment which has a larger cumulative sediment load than any other increment. The duration of the discharges at the upper and lower ends of this effective increment are shown in Table 1. In all cases the duration is based on the seasonal flow and sediment record (April to October). During winter, discharges are consistently low and sediment load is negligible in all these streams, and therefore the sediment load histograms are affected very little by the use of the seasonal records. However, an important consequence of this is that the flow durations of the effective discharge increment are higher (by about one third) than they would be if annual data were used. Where the annual records are sufliciently long, the durations for the effective discharge increment for the annual data are also given in Table 1 and can be compared with the seasonal results for the same streams.

Table 1 reveals a considerable range in duration of the effective discharge from less than $0.1 \%$ of the time to over $40 \%$. It is difficult to identify a modal duration range for the effective discharge, although there is a predominance of values in the range $1-10 \%$. This range of values is more extreme than 

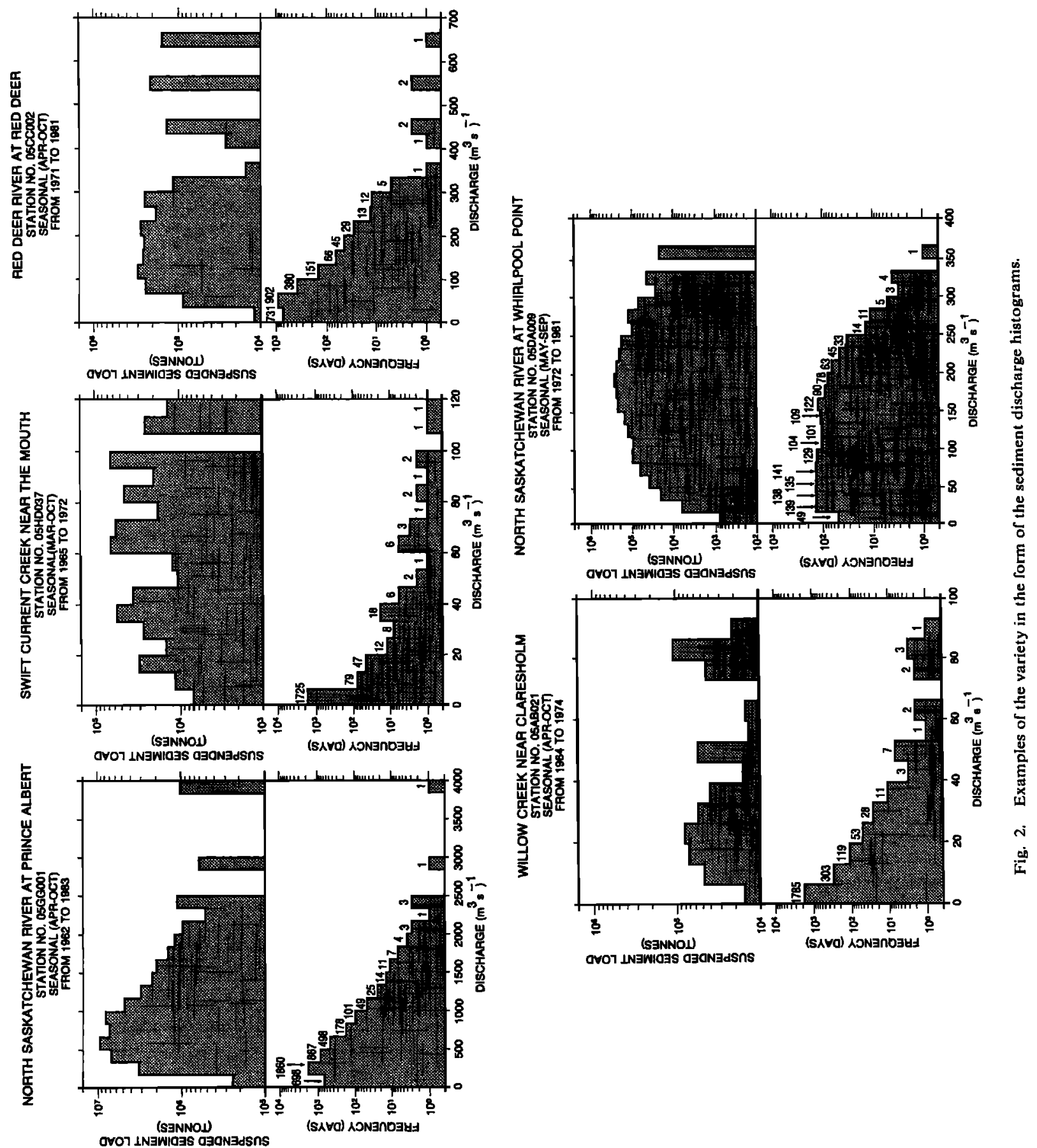


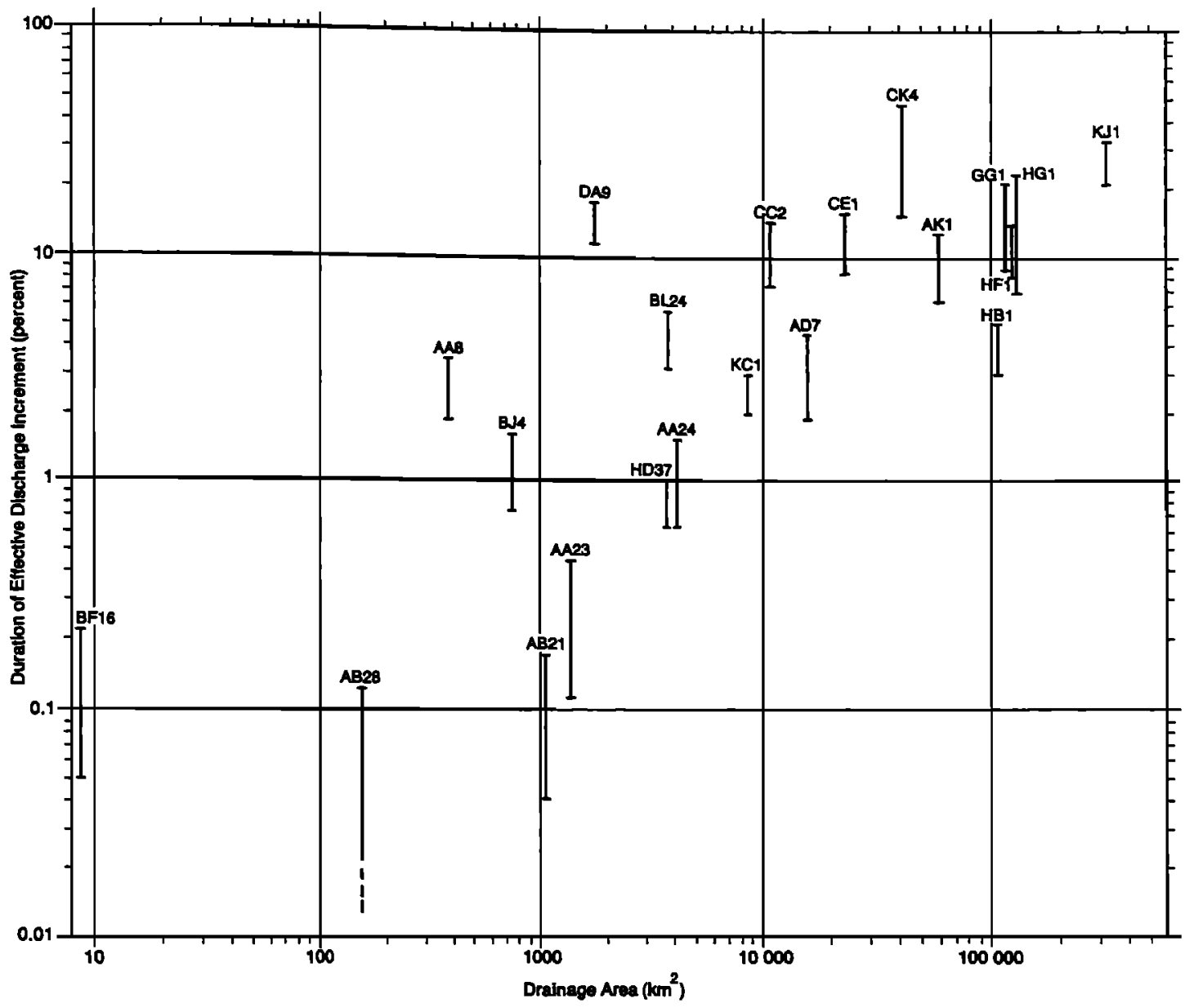

Fig. 3. Drainage basin area versus the percentage duration of the effective discharge increment. Stations are labeled by an abbreviated station number.

any previously reported and does not support any widely applicable generalization about the duration of the effective discharge. These data include sites at which the effective discharge is well in excess of the mean annual flood as well as several at which the effective discharge is exceeded more than $10 \%$ of the time.

A brief inspection of Table 1 reveals that the variation in duration of the effective discharge is related to the drainage area of the streams. This is illustrated in Figure 3 from which it is apparent that the larger basins tend to have effective discharges with higher percentage exceedances, the pattern expected on the basis of previous work by Wolman and Miller [1960] and Andrews [1980]. The result is a downstream trend along the major rivers from small Foothills streams in which the effective discharge is a fairly extreme event occurring 1 day/year or less, to large Prairie rivers in which the effective discharge is a common event exceeded 30 or more days per year. This can be seen in Figure 3 by following the sequence of stations downstream along the Red Deer or Oldman-South Saskatchewan Rivers (see Figure 1). For example, the downstream sequence in percentage duration of the effective discharge at stations along the Oldman-South Saskatchewan River is $0.11-0.45,0.64-1.52,1.87-4.44$, and $6.22-12.54$ for stations 05AA023 (Oldman River at Waldron's Corner), 05AA024 (Oldman River near Brocket), 05AD007 (Oldman River near Lethbridge), and 05AK001 (South Saskatchewan River at Highway 41), respectively.
This relationship between effective discharge duration and drainage area is probably primarily a reflection of differences in discharge regime and flow duration characteristics. Thus for example, the skewness and range of the daily discharges tends to decrease downstream [Ashmore, 1986] and therefore is inversely related to drainage area. An additional factor accounting for this relationship is that in the larger Prairie rivers suspended sediment concentration tends to remain relatively high even at low discharges, perhaps because of a large wash load, which may help explain high frequency of the effective discharge in those rivers.

Another factor to be considered in explaining this downstream trend in the duration of the effective discharge is the effect of flow regulation and consumptive use on the larger streams. In the absence of preregulation data it is impossible to establish the extent of this effect but two points can be made in this connection. First, the downstream increase in the percentage duration of the effective discharge occurs in the Red Deer River which was unregulated during the period for which the analysis was carried out. Second, the potential influence of flow regulation on the effective discharge is unlikely to be great except in two or three cases. Calculation of the natural flow of these rivers by Prairie Provinces Water Board [1982] indicates that in the South Saskatchewan system upstream of Lake Diefenbaker consumptive use has reduced natural flows by about $15-25 \%$. These reductions are fairly evenly distributed through the open water season and there- 
fore there has been no pronounced alteration of the annual flow regime.

In the North Saskatchewan River the annual flow regime has been altered by flow regulation. Average monthly flows in July and April are now almost identical in contrast to the natural regime in which the average July discharge was almost twice that of April. This broader peak to the annual discharge regime may have increased the percentage duration of the effective discharge on the North Saskatchewan River at Prince Albert (05GG001). The same is true of two other stations: South Saskatchewan River at Saskatoon (05HG001) and Saskatchewan River at The Pas (05KJ001), both of which are strongly influenced by upstream reservoirs. Note that the station on the South Saskatchewan River near Outlook (05HF001) was discontinued prior to the impoundment of Lake Diefenbaker and hence the sediment transport data at that site are not influenced by the reservoir.

\section{Conclusions}

The form of the effective discharge histograms and the duration of the effective discharge for suspended sediment transport in streams of the Saskatchewan River basin are highly variable. In a sample of streams with drainage areas ranging from 10 to over $100,000 \mathrm{~km}^{2}$ and with sediment records between 5 and 29 years in length, the duration of the effective discharge is less than $0.1 \%$ in some cases and over $15 \%$ in others, with the majority of stations having values between 1 and $10 \%$. In extreme cases the effective discharge is the largest flow to occur during the period of sediment record. These results are largely based on seasonal records and must be compared cautiously with previous analyses of annual data.

In many cases the effective discharge histograms are not the simple unimodel distributions envisaged by Wolman and Miller [1960] and shown, for example, by Andrews [1980], but rather they have a complex form sometimes having peaks of similar magnitude at two or more discharges with quite different durations.

The duration of the effective discharge is related to the drainage area of the streams, perhaps reflecting differences in the form of the discharge duration curves. The smaller headwaters basins in the Rocky Mountains and Foothills tend to be dominated by the most extreme events, while the large Prairie rivers with Mountain sources are dominated by frequent events with durations often greater than $10 \%$. The high wash load of the large Prairie rivers may also be partially responsible for the frequency of the effective discharge in these rivers. The effective discharge at some stations on the downstream sections of the main stem North Saskatchewan, South Saskatchewan, and Saskatchewan Rivers may be influenced by upstream flow regulation. The tendency in these cases would be to increase the percentage duration of the effective discharge.

It is apparent from these data that the effective discharge for suspended sediment transport may be in many cases an event of moderate magnitude as previously suggested by Wolman and Miller [1960] and confirmed by Andrews [1980]. However, this is not true of all streams; in some cases extreme events may be the effective discharge while in others, particularly those with large drainage areas (greater than 10,000 $\mathrm{km}^{2}$ ), very frequent events transport the greatest proportion of the load. The relationship between effective discharge and bank-full discharge is presumably correspondingly variable, making questionable any generalizations on this point.

Finally, in several streams similar quantities of sediment are transported by flows of quite different magnitude and frequency. In these cases the concept of an effective discharge for suspended sediment transport is inapplicable.

Acknowledgments. The work described in this paper was carried out while the first author held a Natural Sciences and Engineering Research Council of Canada Visiting Fellowship in Canadian Government Laboratories. Thanks to Joseph Mcllhinney for computer programming and to Keith Bigelow and Zofia Wolinski for drafting.

\section{REFERENCES}

Andrews, E. D., Effective and bankfull discharges of streams in the Yampa River basin, Colorado and Wyoming, J. Hydrol., 46, 311330, 1980.

Ashmore, P. E., Suspended sediment transport in the Saskatchewan River Basin, Rep. IWD-HQ-WRB-SS-86-9, Sed. Surv. Sect., Water Surv. of Can., Water Resour. Branch, Inland Waters Directorate, Environment Canada, Ottawa, Ont., 1986.

Baker, V. R., Stream-channel response to floods, with examples from central Texas, Geol. Soc. Am. Bull., 88, 1057-1071, 1977.

Benson, M. A., and D. M. Thomas, A definition of dominant discharge, Bull. Int. Assoc. Sci. Hydrol., 11, 76-80, 1966.

Ferguson, R. I., River loads underestimated by rating curves, Water Resour, Res., 22, 74-76, 1986.

Nolan, K. M., T. E. Lisle, and H. M. Kelsey, Bankfull discharge and sediment transport in northwestern California, Erosion and Sedimentation in the Pacific Rim, IAHS Publ., 165, 439-449, 1987.

Pickup, G., and R. F. Warner, Effects of hydrologic regime on magnitude and frequency of dominant discharge, J. Hydrol., 29, 51-75, 1976.

Prairie Provinces Water Board, Water demand study, Historical and current water uses in the Saskatchewan-Nelson Basin, Prairie Provinces Water Board, 1982.

Richards, K., Rivers: Form and Process in Alluvial Channels, 358 pp., Methuen, London, 1982.

Webb, B. W., and D. E. Walling, The magnitude and frequency characteristics of fluvial transport in a Devon drainage basin and some geomorphological implications, Catena, 9, 9-23, 1982.

Wolman, M. G., and R. Gerson, Relative scales of time and effectiveness of climate in watershed geomorphology, Earth Surf. Processes Landforms, 3, 189-208, 1978.

Wolman, M. G., and J. P. Miller, Magnitude and frequency of forces in geomorphic processes, J. Geol., 68, 54-74, 1960.

P. E. Ashmore, Department of Geography, University of Saskatchewan, Saskatoon, Saskatchewan, Canada S7N OWO.

T. J. Day, Sediment Survey Section, Water Resources Branch, Inlands Waters/Lands Directorate, Environment Canada, Ottawa, Ontario, Canada K1A 0E7.

(Received July 20, 1987;

revised January 29,1988 ;

accepted January 29, 1988.) 